\title{
SIFAT FISIK DAN KANDUNGAN GIZI BUAH JAMBU HUTAN, LEMAS, DAN SIBAU DI KALIMANTAN BARAT
}

\author{
Tendry ${ }^{1}$, Entin Daningsih ${ }^{2}$, Titin $^{3}$ \\ ${ }^{1,2,3}$ Prodi Pendidikan Biologi, FKIP Universitas Tanjungpura \\ Jalan Prof. Dr. H. Hadari Nawawi Pontianak 78124 \\ e-mail: tendry95@gmail.com
}

\begin{abstract}
Abstrak
Berkurangnya luas hutan akibat konversi lahan mengakibatkan buah-buahan hutan sulit ditemui, sedangkan kebanyakan gizi dari buah hutan belum diketahui. Penelitian bertujuan mengetahui sifat fisik dan kandungan gizi buah jambu hutan, lemas, dan sibau di Kalimantan Barat. Metode penelitian dalam pengamatan sifat fisik yaitu deskriptif, sedangkan uji kandungan gizi menggunakan metode eksperimen desain RAL. Pengamatan sifat fisik meliputi warna kulit hingga aroma buah. Sampel diambil dengan teknik random sampling kemudian diuji gizi secara kuantitatif dengan karbohidrat total hingga vitamin C. Hasil uji gizi dianalisis menggunakan SAS versi 6.12 tahun 1996 diikuti LSD $\alpha=0,05$. Hasil penelitian yaitu terdapat perbedaan karakter dari setiap buah dan kandungan gizi buah jambu hutan, lemas, dan sibau yang signifikan. Kandungan air, karbohidrat total, dan vitamin C tertinggi terdapat pada buah jambu air, lemas, dan sibau secara berturut-turut.
\end{abstract}

Kata Kunci: sifat fisik, kandungan gizi, jambu hutan, lemas, sibau.

\begin{abstract}
Forest area reduction due to land conversion threats forest fruits, whereas most nutrients from forest fruits are not yet known. This study aimed at determining the physical properties and nutritional content of 'jambu hutan', 'lemas' and 'sibau' in West Kalimantan. The research method in observing the physical properties was descriptive, while the nutrient content test used experimental design with CRD model. Observations of physical properties covered from skin color to the aroma of the fruits. Samples were taken by random sampling technique and then nutrition was tested quantitatively, ranging from total carbohydrate to vitamin C. Nutritional results were analyzed using SAS version 6.12 in 1996 followed by LSD $\alpha=0.05$ if significans. There were differences in the character of each fruit and nutritional content of the jambu hutan, lemas, and sibau. The content of water, total carbohydrate, and vitamin $C$ was highest in jambu hutan, lemas, and sibau respectively.
\end{abstract}

Keywords: physical properties, nutritional content, jambu hutan, lemas, sibau.

\section{PENDAHULUAN}

Berdasarkan hasil wawancara dengan Pemerintah Kabupaten Landak Kalimantan Barat, 70\% daerah Kecamatan Air Besar Kabupaten Landak Kalimantan Barat masih merupakan hutan wilayah milik warga. Terdapat 4 hutan yang biasa dimasuki oleh warga Kecamatan Air Besar yaitu hutan Sebambung, Berui, Midik, dan Ensiang. Berdasarkan hasil wawancara dengan para petani yang 
biasa memasuki hutan, diketahui bahwa tumbuhan hutan khususnya buah-buahan yang berada di hutan semakin hari semakin berkurang akibat konversi lahan.

Pemerintah daerah memperkirakan hanya tersisa $20 \%$ tumbuhan hutan saja, sedangkan $80 \%$ telah ditanami dengan tanaman sawit dan karet. Pemerintah daerah mengatakan telah terjadi konversi hutan dan mengakibatkan sulit ditemukannya buah-buahan hutan seperti jambu hutan (Syzygium jambos), lemas (Alpinia mutica), dan sibau (Nephelium mutabile).

Buah jambu hutan, lemas, dan sibau merupakan buah-buahan hutan yang biasa dikonsumsi oleh masyarakat Kecamatan Air Besar. Masyarakat Kecamatan Air Besar sebagian besar bekerja sebagai petani. Beberapa dari petani memiliki kebun yang berada di dalam hutan. Pada saat melewati hutan, petani memiliki kebiasaan mengambil buah-buahan yang ada di dalam hutan dan memakannya. Tetapi masyarakat tidak mengetahui kandungan gizi dari buah-buahan yang dimakan tersebut. Kurangnya pengetahuan masyarakat mengenai kandungan gizi buah yang dimakan serta kurangnya pengetahuan masyarakat mengenai sifat fisik dari buah mendukung peneliti untuk mengamati sifat fisik buah dan menguji kandungan gizi buah jambu hutan, lemas, dan sibau.

Zat gizi (nutrient) adalah ikatan kimia yang diperlukan oleh tubuh untuk melakukan fungsinya yaitu menghasilkan energi, membangun, dan memelihara jaringan, serta mengatur proses-proses kehidupan (Rahayu dan Sulisdiana, 2012). Kandungan gizi buah yang dianalisis yaitu kandungan karbohidrat (meliputi karbohidrat total, glukosa, fruktosa, dan sukrosa), kandungan lemak, protein, vitamin $\mathrm{C}$, kadar air, kadar abu, dan serat kasar.

Jika kandungan gizi buah jambu hutan, lemas, dan sibau sudah diketahui, maka masyarakat dapat mempertimbangkan manfaatnya dalam mendukung gizi harian, sehingga masyarakat akan melakukan upaya untuk menjaga kelestarian keanekaragaman hayati di Indonesia, khususnya pada tumbuhan jambu hutan, lemas, dan sibau yang sudah hampir punah di Kecamatan Air Besar Kabupaten Landak Kalimantan Barat. 


\section{METODE}

\section{Pengamatan Sifat Fisik Tumbuhan Jambu Hutan, Lemas, dan Sibau}

Jenis penelitian yaitu penelitian deskriptif. Populasi penelitian yaitu buahbuahan yang ada di hutan Kecamatan Air Besar Kabupaten Landak Kalimantan Barat. Sampel penelitian adalah buah jambu hutan, lemas, dan sibau. Buah yang diambil yaitu buah dalam keadaan segar dan dapat dikonsumsi secara langsung. Pengamatan sifat fisik buah bertujuan untuk menentukan kualitas dari buah yang diambil sehingga data yang diperoleh nantinya akan mendukung kandungan gizi dari buah. Sifat fisik yang diamati yaitu warna kulit muda, warna kulit masak, struktur permukaan kulit, warna daging, warna biji, ukuran buah, bentuk buah, tekstur buah, serta aroma buah yang baru dipetik. Pengukuran kadar gula menggunakan alat refractometer dan tingkat keasaman dengan menggunakan alat indicator Ph universal.

\section{Uji Kandungan Gizi Buah Jambu Hutan, Lemas, dan Sibau}

Penelitian berbentuk eksperimen menggunakan Rancangan Acak Lengkap (RAL). Dengan sembilan kali replikasi dan tiga perlakuan, yaitu buah jambu hutan, lemas, dan sibau. Alat yang digunakan dalam penelitian dibagi atas alat preparasi dan alat dari setiap pengujian kadar kuantitatif kandungan gizi buah jambu hutan, lemas, dan sibau. Alat preparasi yang digunakan yaitu blender, pisau, neraca analitik, neraca ohaus, gelas kimia $250 \mathrm{ml}$, batang pengaduk, dan pipet tetes.

Bahan yang digunakan dalam penelitian untuk setiap jenis buah yaitu 168 gram daging buah jambu hutan, lemas, dan sibau. Selanjutnya, bahan dibagi berdasarkan uji kuantitatif yang dilakukan, 150 gram bahan dihaluskan dan 18 gram bahan tidak dihaluskan. Uji karbohidrat dilakukan menggunakan metode benedict kuantitatif berdasarkan prinsip reduksi $\mathrm{Cu}^{2+}$ menjadi $\mathrm{Cu}^{+}$yang mengendap menjadi $\mathrm{Cu}_{2} \mathrm{O}$ berwarna merah bata (Plummer, 1971). Adapun alat, bahan serta prosedur kerja mengacu pada Plummer (1971).

Uji kadar protein dilakukan dengan menggunakan cara spektrofotometri. Prinsip dari spektrofotometri adalah mengukur jumlah cahaya yang diabsorbsi 
atau ditransmisikan oleh molekul-molekul di dalam larutan. Ketika panjang gelombang cahaya ditransmisikan melalui larutan, sebagian energi cahaya tersebut akan diserap (Rusli, 2012). Uji kadar lemak dilakukan dengan menggunakan soxhlet, yaitu memisahkan lemak atau minyak dari bahan dengan mengekstraksi ke dalam pelarut organik (SNI No. 01-2354.3 dalam Swastawati, dkk., 2013).

Uji vitamin $\mathrm{C}$ dilakukan menggunakan cara titrasi yodium. Prinsip metode titrasi yodium adalah yodium akan mengadisi ikatan rangkap pada $\mathrm{C}$ no. 3 dari vitamin C. Hal tersebut berarti jumlah vitamin $\mathrm{C}$ dalam bahan sebanding dengan iodin yang diperlukan untuk mengadisi ikatan rangkap pada vitamin C. Jika keseluruhan vitamin $\mathrm{C}$ dalam bahan sudah teradisi oleh iod, maka iod bebas yang tersisa akan berikatan dengan indikator amilum membentuk komplek berwarna biru (Sudarmadji, dkk., 1997).

Uji kadar air dilakukan dengan cara gravimetri yang didasarkan dengan penimbangan berat jumlah molekul air yang tidak terikat dalam suatu bahan pangan (Swastawati, dkk., 2013). Pengukuran kadar serat kasar menggunakan metode gravimetri. Metode gravimetri adalah ekstraksi lemak, protein, karbohidrat menggunakan larutan asam dan basa sehingga hanya tertinggal serat kasar, kemudian ditimbang sampai berat konstan (Rahayu dan Sulisdiana, 2012).

Uji kadar abu yang dilakukan menggunakan prinsip pengabuan secara langsung. Adapun alat, bahan serta prosedur kerja uji kadar protein, lemak, vitamin C, air, serat kasar, dan abu mengacu pada Sudarmadji, dkk. (1997). Data kadar kandungan gizi masing-masing jenis buah jambu hutan, lemas, dan sibau dimasukkan ke dalam tabel pengamatan. Kemudian diolah menggunakan aplikasi SAS versi 6.12 tahun 1996 dengan model RAL dianalisis varian (ANOVA). Jika hasil menunjukkan pengaruh yang signifikan, maka dilanjutkan dengan uji Least Square Different (LSD).

\section{HASIL DAN PEMBAHASAN}

\section{Pengamatan Sifat Fisik Tumbuhan Jambu Hutan, Lemas, dan Sibau}

Sebelum dilakukan pengujian kandungan gizi buah terlebih dahulu dilakukan pengamatan sifat fisik dan pengukuran tingkat gula serta keasaman 
buah yang bertujuan untuk menentukan kualitas dari buah yang diambil sehingga data yang diperoleh nantinya akan mendukung kandungan gizi dari buah. Adapun gambar fisik buah-buahan yang akan diuji termuat dalam Gambar 1. Pengamatan sifat fisik buah tertulis dalam Tabel 1. Sedangkan hasil pengukuran kandungan gula dan tingkat keasaman termuat dalam Tabel 2. Adapun hasil penelitian kandungan gizi buah jambu hutan, lemas, dan sibau tertulis dalam Tabel 3.

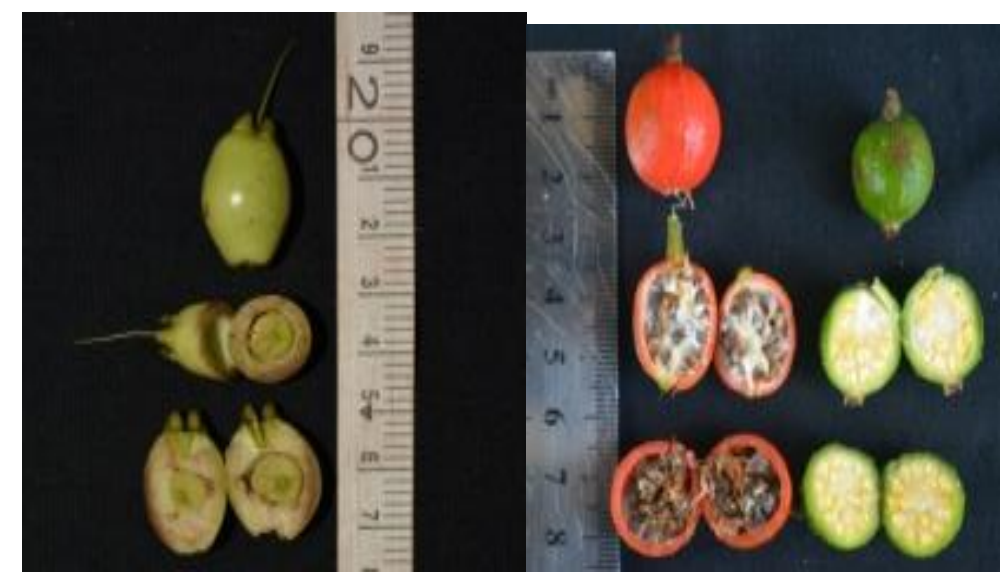

(a)

(b)

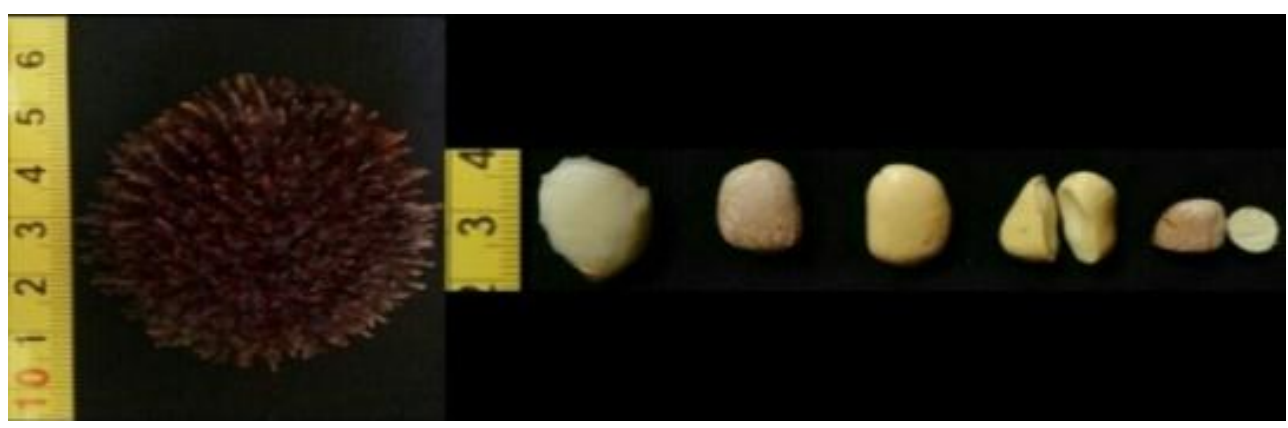

(c)

Gambar 1 Fisik Buah: (a) Jambu Hutan, (b) Lemas, (c) Sibau

Tabel 1 Sifat Fisik Buah Jambu Hutan, Lemas, dan Sibau

\begin{tabular}{cccc}
\hline Karakteristik & Jambu hutan & Lemas & Sibau \\
\hline Warna kulit muda & Putih kehijau-hijauan & Hijau & Hijau \\
\hline
\end{tabular}




\begin{tabular}{lccc}
\hline \multicolumn{1}{c}{ Karakteristik } & Jambu hutan & Lemas & Sibau \\
\hline Warna kulit masak & $\begin{array}{c}\text { Hijau kekuning- } \\
\text { kuningan }\end{array}$ & Merah jingga & Merah tua \\
$\begin{array}{l}\text { Struktur } \\
\text { permukaan kulit }\end{array}$ & Licin & Kasar & Berambut \\
Warna daging & Putih & Cokelat & Putih \\
Warna biji & Cokelat & Hitam & Putih \\
Ukuran buah & \pm 2 cm & $\pm 2 \mathrm{~cm}$ & $\pm 5 \mathrm{~cm}$ \\
Bentuk buah & Lonjong & Bulat & Bulat \\
Tekstur buah & Berair & Kering & Berair \\
Aroma buah & Seperti mawar & $\begin{array}{c}\text { Sedikit berbau } \\
\text { seperti lengkuas }\end{array}$ & $\begin{array}{c}\text { Seperti } \\
\text { rambutan }\end{array}$ \\
\hline
\end{tabular}

Uji Kandungan Gizi Buah Jambu Hutan, Lemas, dan Sibau

Tabel 2 Pengukuran Kandungan Gula dan Tingkat Keasaman Buah Jambu Hutan, Lemas, dan Sibau

\begin{tabular}{lccc}
\hline \multicolumn{1}{c}{ Kriteria yang diukur } & Jambu hutan & Lemas & Sibau \\
\hline $\begin{array}{l}\text { Kadar gula setelah dipetik } \\
\text { (\% brix) }\end{array}$ & 11 & 3 & 27 \\
pH setelah dipetik & 5 & 5 & 3 \\
Kadar gula saat akan di uji & 13 & 2,5 & 26 \\
$\begin{array}{l}\text { \% brix }) \\
\text { pH saat akan di uji }\end{array}$ & 4 & 7 & 5 \\
\hline
\end{tabular}

Pengukuran kandungan gula dan tingkat keasaman yang diamati meliputi kadar gula dan $\mathrm{pH}$ setelah dipetik serta kadar gula dan $\mathrm{pH}$ saat akan di dilakukan 
uji kandungan gizi. Terdapat perbedaan skala hasil pengukuran dari setiap buah. Buah jambu hutan memiliki kadar gula $11 \%$ brix setelah dipetik dari pohonnya, namun mengalami peningkatan pada saat akan diuji yaitu sebesar $13 \%$ brix dengan $\mathrm{pH}$ setelah dipetik 5 dan pada saat akan diuji mengamlami kenaikan menjadi 4. Pada buah lemas kadar gula $3 \%$ brix setelah dipetik, namun mengalami penurunan pada saat akan diuji yaitu sebesar $2,5 \%$ brix dengan $\mathrm{pH}$ setelah dipetik 5 dan pada saat akan diuji mengamlami penurunan menjadi netral. Adapun pada buah sibau kadar gula lebih tinggi dari buah lainnya yaitu $27 \%$ brix setelah dipetik dari pohonnya dan mengalami sedikit penurunan pada saat akan diuji yaitu menjadi $26 \%$ brix dengan $\mathrm{pH}$ setelah dipetik 3 dan pada saat akan diuji mengamlami penurunan menjadi 5 .

Tabel 3 Hasil Analisis Sidik Ragam RAL terhadap Buah Jambu Hutan, Lemas, dan Sibau

\begin{tabular}{lcccc}
\hline \multicolumn{2}{c}{ Parameter yang Diukur } & Jambu Hutan & Lemas & Sibau \\
\hline Karbohidrat total & (gr/100 gr) & $10,82 \mathrm{c}$ & $65,32 \mathrm{a}$ & $12,40 \mathrm{~b}$ \\
Glukosa & $(\mathrm{gr} / 100 \mathrm{gr})$ & $9,33 \mathrm{a}$ & $2,16 \mathrm{c}$ & $6,48 \mathrm{~b}$ \\
Fruktosa & $(\mathrm{gr} / 100 \mathrm{gr})$ & $9,89 \mathrm{a}$ & $2,30 \mathrm{c}$ & $6,90 \mathrm{~b}$ \\
Sukrosa & $(\mathrm{gr} / 100 \mathrm{gr})$ & $9,14 \mathrm{a}$ & $2,12 \mathrm{c}$ & $6,38 \mathrm{~b}$ \\
Serat kasar & $(\mathrm{gr} / 100 \mathrm{gr})$ & $3,65 \mathrm{~b}$ & $35,40 \mathrm{a}$ & $2,03 \mathrm{c}$ \\
Lemak & $(\mathrm{gr} / 100 \mathrm{gr})$ & $1,99 \mathrm{~b}$ & $1,06 \mathrm{c}$ & $6,88 \mathrm{a}$ \\
Protein & $(\mathrm{gr} / 100 \mathrm{gr})$ & $3,65 \mathrm{~b}$ & $2,44 \mathrm{c}$ & $3,70 \mathrm{a}$ \\
Air & $(\mathrm{gr} / 100 \mathrm{gr})$ & $83,07 \mathrm{a}$ & $29,49 \mathrm{c}$ & $76,47 \mathrm{~b}$ \\
Abu & $(\mathrm{gr} / 100 \mathrm{gr})$ & $0,54 \mathrm{~b}$ & $1,76 \mathrm{a}$ & $0,55 \mathrm{~b}$ \\
Vitamin C & $(\mathrm{gr} / 100 \mathrm{gr})$ & $46,93 \mathrm{~b}$ & $0,11 \mathrm{c}$ & $140,30 \mathrm{a}$ \\
\hline
\end{tabular}

Keterangan: Nilai mean dengan huruf yang sama setiap baris berarti tidak mempunyai perbedaan yang signifikan berdasarkan perhitungan LSD dengan taraf kesalahan 5\%. 
Setiap uji kandungan gizi dari setiap jenis buah terdapat perbedaan yang signifikan (Tabel 2), buah yang memiliki kandungan karbohidrat paling tinggi adalah lemas dengan rata-rata 65,32 gr/100 gr, sedangkan buah sibau 12,40 gr/100 gr, dan buah jambu hutan 10,28 gr/100 gr. Perbedaan yang signifikan juga terlihat pada kandungan glukosa antara buah jambu hutan, sibau, dan lemas dengan ratarata secara berurutan yaitu 9,33, 6,48 dan 2,16 gr/100 gr.

Kandungan fruktosa dari yang paling tinggi hingga paling rendang yaitu jambu hutan dengan rata-rata 9,89 gr/100 gr, lemas 2,30 gr/100 gr, dan sibau 6,90 gr/100 gr. Sedangkan kandungan sukrosa antara buah jambu hutan, sibau, dan lemas secara berurutan yaitu 9,14, 6,38 dan 2,12 gr/100 gr. Pada uji serat kasar, terdapat perbedaan yang signifikan, buah yang memiliki kandungan serat kasar paling tinggi adalah lemas dengan rata-rata 35,40 gr/100 gr, sedangkan buah jambu hutan gr/100 gr, dan buah sibau 2,03 gr/100 gr.

Pada uji lemak, terdapat perbedaan yang signifikan, buah yang memiliki kandungan lemak paling tinggi adalah sibau dengan rata-rata 6,88 gr/100 gr, sedangkan buah jambu hutan 1,99 gr/100 gr, dan buah lemas 1,06 gr/100 gr. Pada uji protein, terdapat perbedaan yang signifikan. Buah yang memiliki kandungan protein paling tinggi adalah sibau dengan rata-rata 3,70 gr/100 gr, sedangkan buah jambu hutan 3,65 gr/100 gr, dan buah lemas 2,44 gr/100 gr.

Pada uji air, terdapat perbedaan yang signifikan. Buah yang memiliki kandungan air paling tinggi adalah jambu hutan dengan rata-rata 83,07 gr/100 gr, sedangkan buah sibau 76,47 gr/100 gr, dan buah lemas 29,49 gr/100 gr. Pada uji abu, terdapat perbedaan yang signifikan. Buah jambu hutan dan sibau memiliki rata-rata kadar abu hampir sama yaitu secara berturut-turut 0,54 gr/100 gr dan 0,55 gr/100 gr. Sedangkan kandungan abu lemas 1,76 gr/100 gr dan merupakan kadar abu tertinggi dari ketiga buah tersebut. Pada uji yang terakhir yaitu uji vitamin $\mathrm{C}$, terdapat perbedaan yang signifikan. Buah yang memiliki kandungan vitamin C paling tinggi adalah sibau dengan rata-rata 140,30 gr/100 gr, sedangkan buah jambu hutan 46,93 gr/100 gr, dan buah lemas 0,11 gr/100 gr.

Berdasarkan hasil uji kandungan gizi buah jambu hutan, lemas, dan sibau diketahui bahwa ketiga buah tersebut mempunyai perbedaan yang signifikan 
(Tabel 2). Buah jambu hutan memiliki kandungan air tertinggi dibandingkan buah lemas dan sibau karena tekstur buah jambu hutan berair. Air membantu dalam menjaga suhu tubuh (Tejasari, 2005).

Buah lemas memiliki kandungan karbohidrat total paling tinggi yaitu sebesar 65,32 gr/100 gr. Buah lemas memiliki rasa manis. Pernyataan tersebut sejalan dengan pendapat Hamidah (2015) bahwa kandungan karbohidrat pada buah juga berpengaruh pada rasa yaitu perimbangan antara gula dan asam. Fungsi karbohidrat yaitu sebagai sumber energi, oleh karenanya mengonsumsi buah lemas dapat menambah energi. Selain kadar karbohidrat total, buah lemas juga memiliki serat kasar tertinggi yaitu sebesar 35,40 gr/100 gr.

Kandungan serat kasar yang tinggi dikarenakan buah dimakan bersamaan dengan biji. Serat makanan mempunyai banyak manfaat kesehatan serta mempunyai kemampuan mencegah berbagai macam penyakit yang berhubungan dengan sistem pencernaan manusia, seperti konstipasi (sulit buang air besar), diverticulosis (bintil-bintil pada dinding usus), hameorhoid (ambeien), tumor, dan kanker pada saluran pencernaan serta usus buntu (Raharja, dkk., 2004).

Kadar vitamin C paling tinggi terdapat dalam buah sibau yaitu 140,30gr/100 gram karena buah sibau memiliki rasa asam dan terkstur buah berair. Vitamin $\mathrm{C}$ banyak dikandung oleh buah-buahan. Fungsi utama buah-buahan sebagai vitamin $\mathrm{C}$ adalah untuk sintetis kolagen (misalnya untuk tulang, kartilago, gusi), antioksidan membantu dalam detoksifikasi memperbaiki absorpsi besi. Vitamin C berperan sebagai antioksidan yang kuat yang dapat melindungi sel dari agen-agen penyebab kanker dan secara khusus mampu meningkatkan daya serap tubuh atas kalsium (mineral untuk pertumbuhan gigi dan tulang) serta zat besi dari bahan makanan lain (Godam dalam Rachmawati, dkk., 2009).

Kandungan vitamin $\mathrm{C}$ pada buah sibau lebih tinggi dibandingkan dengan kadar vitamin $\mathrm{C}$ pada buah jeruk navel. Rata-rata kadar vitamin $\mathrm{C}$ jeruk navel sebesar 115,13 gr/100 gr (Welya, 2016). Selain kadar vitamin C, kadar air pada buah sibau juga cukup tinggi yaitu sebesar 76, 47 gr/100gr. Buah jambu hutan, lemas, dan sibau memiliki potensi untuk dibudidayakan karena antara buah yang 
satu dengan buah lainnya memiliki kandungan gizi yang berbeda, kandungan gizi yang berbeda pada buah dapat menutupi kekurangan gizi tertentu pada seseorang.

Dari ketiga buah tersebut yang memiliki potensi paling tinggi untuk dibudidayakan adalah buah sibau karena buah tersebut sudah diperjualbelikan oleh masyarakat. Buah sibau sudah ditanam di pekarangan rumah, sedangkan untuk buah jambu hutan dan lemas sulit untuk dilakukan pembudidayaan karena kondisi lingkungan yang harus berada di tepian sungai. Oleh karenanya, usaha konservasi sangat diperlukan agar tumbuhan-tumbuhan tersebut tidak punah.

\section{SIMPULAN}

Berdasarkan hasil analisis data, dapat disimpulkan: (1) Terdapat perbedaan fisik antara buah jambu hutan, lemas, dan sibau; (2) Terdapat hasil yang signifikan pada kandungan gizi buah jambu hutan, lemas, dan sibau; (3) Buah jambu hutan memiliki kandungan air lebih tinggi dibandingkan buah lemas dan sibau. Air membantu dalam menjaga suhu tubuh; (4) Buah lemas memiliki kandungan karbohidrat total lebih tinggi dibandingkan buah jambu hutan dan sibau. Karbohidrat berfungsi sebagai sumber energi; dan (5) Buah sibau memiliki kandungan Vitamin $\mathrm{C}$ lebih tinggi dari buah jambu hutan dan lemas. Vitamin $\mathrm{C}$ berperan sebagai antioksidan yang kuat.

\section{UCAPAN TERIMA KASIH}

Terima kasih kepada tim payung penelitian dengan tema "Buah Langka Kalimantan Barat" dengan dana mandiri, FKIP UNTAN yang telah memberikan bantuan dana DIPA serta Kepala Laboratorium Kimia Pangan Fakultas Pertanian Universitas Tanjungpura yang telah memfasilitasi sarana dalam pengujian kandungan gizi buah.

\section{DAFTAR PUSTAKA}

Hamidah, S. 2015. Sayuran dan Buah serta Manfaatnya bagi Kesehatan. Artikel Ilmiah. Fakultas Teknik Universitas Negeri Yogyakarta. 
Plummer, D. T. 1971. An Introduction to Practical Biochemistry. New Delhi: Mc. Graw-Hill Publ.

Rachmawati, Rani, Made, R. D., Sutiani, \& Ni, L. S. 2009. Pengaruh Suhu dan Lama Penyimpanan terhadap Kandungan Vitamin C pada Cabai Rawit Putih (Capsicum frustescens). Jurnal Biologi XIII. Volume 2: 36 - 40.

Raharja, Sapta, Imam, P., \& Fitria, Y. 2004. Ekstraksi dan Analisa Dietary Fiber dari Buah Mengkudu (Morinda citrifolia). Jurnal Teknik Industri Indonesia Pert. Volume 14: 3-30.

Rahayu \& Sulisdiana. 2012. Hubungan Status Gizi Remaja Putri dengan Siklus Menstruasi MTs Darum Najah Gading Dusun Sumber Kenanga Jatirejo Mojokerto. Hospital Majapahit. Volume 2: 226-232.

Rusli, R. 2012. Penetapan Kadar Boraks pada Mie Basah yang Beredar di Pasar Ciputat dengan Metode Spektofotometri UV-VIS Menggunakan Pereaksi Kurkumin. Skripsi. Jakarta: Fakultas Kedokteran Dan Ilmu Kesehatan UIN Syarif Hidayatullah.

Sudarmadji, Slamet, Haryono, Bambang, \& Suhardi. 1997. Prosedur Analisa untuk Bahan Makanan dan Pertanian. Yogyakarta: Liberty.

Swastawati, Fronthea, Surti, Titi, Agustini, Tri, W., \& Riyadi, P. 2013. Karakteristik Kualitas Ikan Asap yang Diproses Menggunakan Metode dan Jenis Ikan Berbeda. Jurnal Aplikasi Teknologi Pangan. Volume 2.

Welya, S. 2016. Kelayakan Poster pada Sub Materi Zat Makanan Kelas XI dari Hasil Uji Kandungan Gizi dan Serat Buah Jeruk (Citrus sp) yang Diperjualbelikan di Kota Pontianak. Skripsi. Pontianak: Fakultas Keguruan dan Ilmu Pendidikan Universitas Tanjungpura. 